\author{
WOLDETSADIK MESSASH KASSAYE, \\ PhD Student in Peace and Security, \\ Institute for Peace and Security Studies (IPSS), Addis Ababa University, Ethiopia
}

\title{
USEFULNESS OF HUMAN SECURITY CONCEPT: AFRICAN PERSPECTIVE
}

This article is devoted to analysis the value of the human security concept to African nations. The value of the concept is examined in seven different ways. First, it sends a message to state politicians that their responsibility goes beyond state sovereignty. Second, it creates shared responsibility towards local and regional peace and security. Third, it brought improvement in socio-economic aspects. Fourth, it launches diversified responses to achieve conflict agenda. Fifth, it asserts accountability is at the corner for any wrong doings. Sixth, it allows AU and decision making bodies of sub-regional organizations and states to make informed decision based on research and thorough analysis. Seventh, it is pushing Africans to find alternative source of funding. In general, it should be noted that the use of the concept of human security ensures adequate social transformations in modern Africa.

Key words: Africa; human development; human security; state security; security.

Introduction. The security notion during the Cold War era was characterized by defending sovereignty and territorial integrity through military action against external threats and high public spending on defense institutions. Yet, once the state of political tension between east and west bloc ended, overwhelming military and non-military incidents call for attention on human safety [Owen, 2004]. These include but not limited to proliferation of violent conflicts, terrorism, market deregulation, development of informal economies, technological advancement, crimes, massive human right abuses, human security violations and spread of diseases [Fukuda-Parr, 2003; United Nations Development Programme, 2005; United Nations Educational, 2008].

Such scenarios reinforce action over emerging security threats, budget allocation on welfare and work on extending the potential of people [Dikici, 2015]. Besides, it allow intervention of external actors to deal with domestic humanitarian crisis which put the sovereignty of nations under question mark and undermine the popularity of statecentric formulation at large [Adeniyi, 2017]. Issues like terror attacks, HIV, money laundry, human trafficking and illegal weapons trade, economic recession and environmental degradation on the other hand become borderless challenges that affect all nations around the globe [FukudaParr, 2003]. Such developments shift the attention of security from individual states to global level and call for integration.

Even though human security notion is relevant to all kinds of people around the globe, both rich and poor, its significance in developing economies seem higher. Africa as a landmass challenged by economic, social, political and cultural instability more than any continent in the world could benefit from the concept to come out of deprivation and be on the path of sustainable development.

Research Analysis and Research Publications on this Issue. The notion of human security is broad and argumentative. To this end, writings on theoretical, analytical and operational aspects at global and regional level are consulted to properly examine the aptness of the concept to African realities. Among the studies devoted to this problem, it should be noted the researches of such scientists as A. Acharya, A. Adeniyi, A. S. Bah, E. Choge-Nyangoro, S. Dersso, B. Mofya, T. Murithi, P. Collier, C. Elowson, A. Lins de Albuquerque, K. Hussein, D. Gnisci, J. Wanjiru, O.S. Mahmood, N.C. Ani, T. Owen, S. Wierzbicki, R. Tarasiuk and others.

Purpose. Since human security concept entertains wider socio-economic and political issues, this article analyzes the value of the human security concept to African nations. The value of the concept is examined in seven different ways.

\section{What is Human Security?}

Though no unified definition of human security is present, the conception of numerous scholars, states and institutions gave the basics on what it tries to address within the wider security debate. For instance; the pioneering statement by the United Nations Development Programme (UNDP) in the 1994 Human Development Report list out seven key categories in defining the scope of human security. Accordingly, human security entails: economic security (e.g. assured basic income), food security (e.g. access to food and affordability), health security (e.g. protection from diseases and unhealthy lifestyle), environmental security (e.g. protecting the environment from natural and man-made threats), personal security (e.g. ensuring individual's safety from physical torture, criminal acts, war, domestic violence, traffic accidents), community security (e.g. protection of traditional values) and political security (e.g. honoring basic human rights).

The 1994 publication critiques the traditional understanding of security as a narrow interpretation and inconsiderate of people's legitimate concerns about their welfare in daily life. It further contends, the secret of achieving foremost goals like peace, democratization and social integration lies within sustainable development [FukudaParr, 2003]. For sustainable development to happen, states 
are expected to address deep-rooted economic, political and social problems internally [Fukuda-Parr, 2003]. The Commission on Human Security [2003], in its report Human Security Now; also affirms the importance of dealing with structural issues like deprivation, exclusion and inequality to boost the confidence of individuals and ultimately bring equitable development.

Development economists also support prior views. For example, the notion of human development as introduced by the late Pakistani international development theorist Haq suggested development cannot be solely viewed as a function of economic progress but have to deal with getting rid of facets that hamper people from extending their potential [Acharya, 2007]. These include; illiteracy, low income and low life expectancy as captured by Human Development Index (HDI) which is an indicator of development among other measurements by which states progress is measured [Commission on Human Security, 2003]. Therefore, the fact that human development embrace on what to safeguard to make people's life better, apart from military and financial means add to the relevance of human security approach.

Kofi Annan [2001, December 10] also stressed; the need to go beyond sovereignty of states, have deepened understanding on global challenges of 21 st century like terrorism, impoverishment, religious extremism and bad governance and address them in an integrated manner by placing the peace, dignity and security of people at the center. He further noted the need to focus on improving the lives of women, men, children, immigrants and minorities despite of region, race, faith or wealth [Annan, 2001]

The Human Security Network ${ }^{1}$ on the other hand provides an overarching explanation on human security. Accordingly, it works to achieve freedom from fear and freedom from want. The former refers to protection of people from threats like physical violence, armed conflicts, and war through measures like ban on illegal landmines, presenting criminals before International Criminal Court (ICC) and designing a peace building architecture [Owen, 2004]. In contrast, the latter, deals with liberation from nonviolent threats to people's welfare and dignity like poverty, malnutrition, diseases, environmental degradation and others [Acharya, 2007]. While few focus on either of the narrow or broad formulations, most try to reconcile the differences between them by identifying complementary objectives. Obama [Obama, 2009: p. 41] also declared the value of both freedoms by saying "for true peace it is not just freedom from fear, but freedom from want."

Generally, human security is people-centered, comprehensive and development oriented. What is more, it emphasizes the need to integrate efforts of donors, national counterparts, UN agencies, civil society and local communities [Owen, 2004; Fukuda-Parr, 2003]. To make analysis and operationalization feasible, it is also advisable to make it context specific [Gomez, Gasper, 2013]. And the fact that states in today's world are disrupt by various forms of economic, social, political, environmental and cultural crisis is driving nations to revisit their policies and identify highest priority spending areas towards security provision.

\section{Promotion of Human Security}

Various actors take central part in reshaping the traditional security perspective and further the protection and empowerment agenda. The role of Anti-Personnel Landmines Convention in 1997 to abolish the production and use of anti-personnel landmines worldwide, the establishment of International Criminal Court (ICC) in 2002 with the goal to take action against people who are ac- cused of war crimes and crimes against humanity, foundation of Commission on Human Rights (CHR) in 2001 and its efforts to mainstream protection and empowerment strategies; and the formation of United Nations Peace building Commission in 2005 to assist states in post-conflict reconstruction play a huge role in publicizing human security.

Moreover, the launch of United Nations Trust Fund for Human Security (UNTFHS) in 1999 to finance projects that deal with protection and empowerment of people, the formation of International Coalition for the Responsibility to Protect (ICRtoP) in 2009 to stop genocide, war crime, ethnic cleansing and crimes against humanity and the setup of Human Security Network (HSN) to promote human security concept in alliance with academicians and civil society contributed immensely in endorsing human security approach [Acharya , 2007; United Nations Trust Fund for Human Security, 2017].

The fact that human security agenda had gained acceptance by regional organizations like Organization of American States (OAS), European Union (EU), African Union (AU), the New Partnership for Africa's Development (NEPAD), Organization for Security and Co-operation in Europe (OSCE), Asia-Pacific Economic Cooperation (APEC) and the Arab Maghreb Union is another positive achievement to safeguard human lives [United Nations Educational..., 2008].

The presence of UN specialized agencies like UNDP, United Nations Educational, Scientific and Cultural Organization (UNESCO), United Nations High Commissioner for Refugees (UNHCR), United Nations International Children's Emergency Fund (UNICEF), United Nations Development Fund for Women (UNIFEM), Joint United Nations Programme on HIVIAIDS (UNAIDS) and other international NGOs like International Committee of the Red Cross (ICRC), Save the Children and Amnesty International also play key role in promoting human security concept and assist nations in development and relief works [Acharya, 2007; United Nations Trust Fund..., 2017].

\section{Debates on Human Security Concept}

Despite the fact that human security is placed at the heart of global developmental and political agenda; its conceptual, analytical and operational value is an on-going topic of debate. Below, major criticisms and counterarguments by human security advocates are presented.

Lack of Definitional Boundary

One critical concern over human security is lack of unified definition. It covers wide range of psychological, social, economic, political and cultural concerns that threaten people's mental and physical state as well as relationship [Hussein, Gnisci, Wanjiru, 2004]. Hence, it is difficult to comprehend what it is not [Paris, 2001]. What is more, policy objectives are treated as squarely valid and this gives policy makers and academicians hard time to prioritize goals and produce specific research questions [Paris, 2001].

In contrast, advocates contend the concept's comprehensiveness is its major strength. Gomez \& Gasper [Gomez, Gasper, 2013] for instance reflect the focus of human security analysis on multiple-issues help to pinpoint actual, perceived and future threats. Fukuda-Parr [Fukuda-Parr, 2003] also argue, richness of the concept creates opportunity to deal with emerging issues like drug related crimes, human trafficking and money laundry that were not included in development or conflict agenda before.

Narrow or Broad Formulation?

Another concern that came out boldly is whether to focus on freedom from fear or freedom from want. Owen T. [2004] in summarizing the argument regarding the two notions reflect that,

\section{СХІД № 5 (157) вересень-жовтень 2018 р.}


In fact, most of the significant policy advances achieved in the name of human security have used this narrow definition. For instance, the Mine Ban Convention, the International Criminal Court, as well as the recent international focus on child soldiers, small arms and the role of non-state actors in conflict, have all been undertaken using a narrow human security perspective [Owen, 2004: 19].

The above extract implies, freedom from fear have exhibited visible success in protecting people from eminent physical danger. This line of argument gains the support of states like Canada [Paris, 2001].

Others contend, the differences between the two schools of thoughts seem overstated. The fact that both are people-centered, challenge the traditional state security perspective, stress on safety and acknowledge the effect of globalization on individual's wellbeing narrows the gap [Acharya, 2007; Gomez, Gasper, 2013]. Moreover; most violent conflicts have structural causes rooted in resource scarcity, unemployment and social injustice as violent conflicts like war directly or indirectly result impoverishment, diseases, human right abuses and environmental stress [United Nations Development..., 2005].

This explains, if governments fail to address underlying causes, there is high chance to enter or to relapse to conflict. On the other hand, if conflicts cannot be prevented, the damage on economy, social fabrics and environment is inevitable which again can exacerbate the violence. For this very reason, Kofi Annan [Annan, 2001] emphasize the issues in human security approach are in fact interconnected and achieving one is hardly possible without progress in the other.

Measurement Challenges

Ever since the security notion extended from state to individuals safety and freedom, operationalization became a tough task. What is more, finding a legitimate global scale data on a wide array of threats seem impossible probably because institutions with capacity to compile such huge data set are rare and most of them have mandate to prioritize one threat from the other [Owen, 2004]. On top of all, the fact that human security offers a wake-up call to rethink over conditions that we usually ignore, make data availability and measurement complex [Owen, 2004]. The contradiction between objective and subjective measures is also another issue [Owen, 2008].

To ease the challenges of measurement though; broad frameworks like Generalized Poverty, Human Security Audit, the Global Environmental Change and Human Security (GECHS) Index of Human Insecurity (IHI) and the Human Security Report tried to redefine human security and suggest what to measure along with methodology to collect and analyze data (ibid). In summarizing what need to be done to accurately measure broad conception of human security, Owen in his two articles published in 2004 and 2008 argued, knowing relevant harms for a certain region rather than global scale and layering this human security data in Geographic Information System (GIS) can help researchers and policy makers to find hot spots of aggregate human insecurities, obtain measurable list and determine the association between various human security threats. However, to date, no consensus has been reached on how to operationalize the concept.

Undermined State Role

The traditional notion of security glorifies the role of the state in providing protection and proponents of this view contend human security undermines significance of state in the security classroom [Acharya, 2007]. On the other hand, the 2003 Human Security Report remarked, human security and state security are complimentary as long as good governance is put in to effect by the state. They become adversative when governments intimidate citizens through repressive rule, are unable to provide basic social services and acquire dysfunctional institutions to accommodate various interests of social groups [United Nations Development..., 1994; United Nations Development..., 2005].

In discussing new threats to human security, FukudaParr [Fukuda-Parr, 2003] also note the presence of corrupt statesmen and absence of strict laws has worsened crimes like human trafficking in some states. The engagement of humanitarian organizations in relief and development assistance is also to fill the gap that states cannot deliver [Acharya, 2007]. These reveals, states shall not be primal source of protection of people and the principle of 'multiple-providers of human security' is indeed vital to protect people from their own state [Gomez, Gasper, 2013; Hussein, Gnisci, Wanjiru, 2004].

Although human security supposedly claim integration among several players and succeed to do that in various occasions, overdeveloped military response to security challenges in developed and developing nations undermine its effectiveness [Hussein, Gnisci, Wanjiru, 2004; United Nations Educational..., 2008]. This in turn can create insecurity especially among nations with authoritarian rule.

Dependency Syndrome

Humanitarian organizations have become the major players in operationalizing human security agenda by facilitating development efforts primarily led by national leadership. Aid from donors can advance provision of basic goods and services, productivity, investment and living standard of the poor if properly managed [United Nations Development..., 2005]. However, their effectiveness is debatable because local governments become reluctant to take the lead on development efforts due to the flow of large sums. To make matters worse, the aid money is exposed to corruption and mismanagement. For this reason, those contend intervention principle create dependency, undermine the capacity of developing states to respond to domestic problems and erode democracy are many [Hussein, Gnisci, Wanjiru, 2004]. The situation is worse in Africa [Al Jazeera News- Africa, 2018].

Even though donor agencies are considering budget cut and pushing developing states to find alternative sources of funding at local or regional level for peace and developmental operations; the fragile social, economic and political situation in emerging economies constantly call for help and stay in need in the future unless a dynamic approach is devised [Collier, 2015].

4. Usefulness of Human Security Concept to Africa

Previous sections showed the essence of human security concept as well as efforts to promote it at international level. In contrast, its weaknesses are also indicated from conceptual to implementation level. Taking these facts in to consideration, this part discusses how the concept is understood and valued in African context.

African Conception of Human Security

Many countries in Africa have suffered from extreme poverty, hunger, famine, water stress, disease, illiteracy, unemployment, human rights violation, loss of lives and sexual exploitation due to prolonged civil wars, stateperpetrated violence, ethnic hostility, absence of good governance, uncontrolled arms trade, poor resource conservation, conflict resources and radicalism over the years [Collier, 2015; Elowson, Lins de Albuquerque, 2016; Guehenno, 2017; United Nations Development... 2016; United Nations Educational... 2008; Wierzbicki, Tarasiuk, 2017 .

The above scenarios were exemplified in 20 and 40 
years of civil war in Sudan and Democratic Republic of the Congo (DRC) [Guehenno, 2017]; Rwandan genocide [Commission on Human Security, 2003]; repressive regimes during Doe's and Taylor's term in Liberia; diamond conflict in Angola and Sierra Leone [Collier, 2015]; attacks against governments and local communities in Mali, DRC and Somalia due to uncontrolled arms [Adeniyi, 2017]; high rate of sexual exploitation of women and high rate of maternal mortality in Sub-Saharan Africa [United Nations Development..., 2016] and high-profile attacks by alShabaab and Boko Haram in East and West Africa [Collier, 2015] among others.

Few but deadly menaces explained imply that, the lives of African communities are indeed challenged by violent and non-violent risks and individuals, their relationships and the environment they live in are affected by these threats directly or indirectly. Due to these, the traditional and modern concepts of human security in Africa are people-oriented. The indigenous versions of human security concept voiced in Julius Nyerere, Kwame Nkrumah and Leopold Sedar Senghor's philosophies and discourses way before the UNDP's 1994 formulation understood security as the primacy of basic human needs and a means for feasible social and political engagement [Hussein, Gnisci, Wanjiru, 2004]. Likewise, AU's policy documents reveal similar notion.

Values of Human Security Concept

Various developments immerse human security concept to be an integral part of development and conflict agenda around the globe. Africa also benefit from the concept in several ways. Some of them are discussed hereunder.

First, it sends a message to state politicians that their responsibility goes beyond state sovereignty. Before AU's establishment, the primary aim of OAU was to crate independent states free from colonialism [Bah, ChogeNyangoro, Dersso, Mofya, Murithi, 2014]. This aspiration, though critical at the time, made the responsibility of government confined to territorial defense. The OAU did not take measures over intensified intra and inter-state conflicts of member states [Bah, Choge-Nyangoro, Dersso, Mofya, Murithi, 2014]. However, the founding principles of $\mathrm{AU}$ : accelerating political and socio-economic integration of African states; promoting peace, security, democracy and good governance and value for gender equality put the issue of sovereignty conditional up on the ability of state to look after its people and show its commitment towards people's safety and welfare [Bah, ChogeNyangoro, Dersso, Mofya, Murithi, 2014].

The freedom from fear and want aspirations of $A U$ are also shared by sub-regional communities like the InterGovernmental Authority on Development (IGAD), the Eastern African Community (EAC), Economic Community of West African States (ECOWAS), Southern African Development Community (SADC), Common Market for Eastern and Southern Africa (COMESA), Community of Sahel-Saharan States (CEN-SAD) and the Arab Maghreb Union [Elowson, Lins de Albuquerque, 2016; Wierzbicki, Tarasiuk, 2017]. Despite economic integration, currently, all sub-regional communities embrace peace and security agenda [African Union Commission, 2015].

Second, it creates shared responsibility towards local and regional peace and security. Prior discussions imply that, human insecurity is becoming a borderless issue and joining forces to fight back seem the only alternative. In this vein, $A U$ made normative transition in nonintervention principle. Hence, intervention in the domestic affairs of states to protect people from severe human rights violation is allowed [Bah, Choge-Nyangoro, Dersso, Mofya, Murithi, 2014].

In practical terms, peace keeping missions by $\mathrm{AU}$ and sub-regional communities in collaboration with external actors indeed save nations from further escalation of war. Even though the effectiveness of such missions is undermined due to various factors; engagement of ECOWAS in disarmament, coordinating relief work and peacekeeping in Liberia during and after Liberian second civil war through ECOMIL and the ongoing force African Union Mission in Somalia (AMISOM) since 2007 are examples that regional organizations and member states show commitment towards citizens in another state ${ }^{3}$ [Mahmood, Ani, 2017].

As explained under section 2 , human security supports coordination among various actors including civil societies and international community. For instance, the Economic, Social and Cultural Council (ECOSOCC) of AU is intended to foster growth for African Civil Societies and have active role in implementation of AU's policies and programs [African Union Commission, 2015]. Alliance of African states with UN, US, UK, Canada, EU, G8 and other Western as well as other African Development agencies contribute for the improvements in security sector and human development [Hussein, Gnisci, Wanjiru, 2004].

Third, it brought improvement in socio-economic aspects. Institutionally, African Central Bank, African Investment Bank and African Monetary Fund within AU help to practice the economic integration agenda [African Union Commission, 2015]. As a result of policy initiatives and interventions, strong domestic demand and a positive economic growth are also shown in most of non-commodity exporting African countries despite the slowdown in 2016 [African Development Bank..., 2017]. Human development level also rise between 1990 and 2015 from 0.35 to 0.65 approximately in which North Africa recorded the most progress [African Development Bank..., 2017].

Multi-dimensional poverty also reduced in 30 countries out of 35 states like in Rwanda, Ghana, Liberia and DRC [African Development Bank..., 2017]. Moreover, investment on education and social protection programs scale up [African Development Bank..., 2017]. For instance percentage of government expenditure on education in Sub-Saharan Africa between 2010 and 2014 was $16.37 \%$ way higher that world average which account to $14.13 \%$ [African Development Bank..., 2017]. The social protection program was also able to save approximately 7.5 million people only in Ethiopia in 2009 [United Nations Development..., 2016].

In relation to health, progress is made in reducing the human cost of malnutrition in Africa. A case in point is the change in Sub-Saharan Africa. Here, the prevalence of malnutrition among children under five years of age goes down to $35 \%$ in 2012 from $45 \%$ in 2005 [African Development Bank..., 2017]. School meal programs in Botswana, Cote d'Ivoire, Ghana, Mali, Namibia and South Africa provide children with notorious meals and motivate them to stay in school [United Nations Development..., 2016].

With regard to maternal mortality, the ratio has decreased from 1000 deaths per 100,000 live births in 1990 to 550 in 2015 in Sub-Saharan Africa and from 175 to 75 in North Africa [Alkema, Chou, Hogan and others, 2015]. On the subject of HIV, African countries adopt HIVIAIDS programme and review testing and treatment guidelines through technical and financial support of international allies [World Health Regional Organization Office..., 2017]. 
The improved testing coverage in states like South Africa and Botswana is a striking example [World Health Regional Organization Office..., 2017].

Since around $23 \%$ of deaths in Africa have environmental causes, African states with the help of $\mathrm{WHO}$ and other partners, undertake comprehensive assessment at local and regional level on water and sanitation issues and climate change [World Health Regional Organization Office..., 2017]. Hence, the Water and Sanitation for Health Facilities Improvement Tool (WASH FIT) is introduced to countries like Chad, Guinea, Senegal and Sierra Leone and regional response plan towards extreme climate induced events like drought and flooding was developed to East and South African regions in 2015 [World Health Regional Organization Office..., 2017].

Protocol to the African Charter on Human and Peoples' Rights on the Rights of Women in Africa in 2003 and Solemn Declaration on Gender Equality in Africa in 2004 provides a guideline on how African governments and subregional organizations work towards gender equality and empowerment of women and girls in Africa ${ }^{4}$. Moreover, several African countries implement legal frameworks against harmful practices like Female Genital Mutilation (FGM), early marriages and acid violence [United Nations Development Programme, 2016].

Fourth, it launches diversified responses to achieve conflict agenda. The presence of military and non-military approaches to tackle security threats in Africa is mainly attributed to human security concept. A positive step towards conflict prevention, early warning, peace building, postconflict reconstruction, promotion of democracy and good governance and humanitarian action was made through the emergence of African Peace and Security Architecture (APSA) by AU [Bah, Choge-Nyangoro, Dersso, Mofya, Murithi, 2014].

As a decision making organ of APSA - the Peace and Security Council (PSC) is also mandated for conflict prevention, military intervention and imposition of sanctions at time of unconstitutional government change through its structures Continental Early Warning System (CEWS), Panel of the Wise, African Stand by Force (ASF) and the Peace Fund [African Union Commission, 2015]. The Council integrates its CEWS wing to sub-regional communities to pin point potential threats at regional level [African Union Commission, 2015].

Practically, PSC has contributed to the resolution of many conflicts by itself and in collaboration with subregional communities in Somalia, Burundi, Mali, the Democratic republic of the Congo, Madagascar, Côte d'Ivoire, Central African Republic (CAR), Guinea Bissau, Sudan, South Sudan, Guinea, Niger, and Kenya [African Union Commission, 2015]. The Commission also assigned special high level representatives and envoys to conduct structured mediation across the continent. In 2015 only, 25 agents were on duty [African Union Commission, 2015].

To reduce the rate of conflict relapse in Africa; Disarmament, Demobilization and

Reintegration (DDR) initiatives are in place with the objective of removing arms of former combatants including child soldiers and engage them in education and training to learn new skills and re-integrate to the society. For instance; in the Multi-Country Demobilization and Reintegration Program (MDRP), which was the largest DDR program in the Great Lakes region of Central Africa, around 300,000 ex-combatants in Angola, Burundi, CAR, DRC Rwanda and Uganda were reached ${ }^{5}$ [Hanson, 2007]. The $\mathrm{AU}$ Disarmament, Demobilization and Reintegration

${ }^{4}$ http://www.un.org/en/africa/osaa/peace/women.html
Capacity Programme (AU DDRCP) is also providing assistance to member states since 2013 [African Union Commission, 2015].

To combat illicit trade on small arms and light weapons (SALW) and better manage weapons stockpiles which infamously linked to armed violence, deaths and mass dislocation, African states show commitment towards treaties under international law and legally-binding regional agreements. Till July 2017, 39 African states signed the international accord-Arms Trade Treaty (ATT) and Countries like Sudan which involved in the longest civil war in Africa also signed the Nairobi Protocol to control and reduce SALW in the Horn [Adeniyi, 2017; Kytomaki, 2017]. Sub-regional communities also adopt SALW and take exemplary step in this area [African Union Commission, 2015].

Moreover, the Panel of the Wise and corresponding structures within RECs were involved in preventive diplomacy and mediation. In 2015 for instance, COMESA and EAC collaborate to mediate the Burundi crisis [African Union Commission, 2015]. The IGAD also had a mediating role in South Sudan's civil war in 2013 [Elowson, Lins de Albuquerque, 2016]. On the other hand, the Accra Comprehensive Peace Agreement in 2003 which lead to the cessation of Liberian second civil war Lead by Nigeria and Sudan Peace Agreement in 2005 which leads to South Sudan's independence lead by IGAD are few of the nonmilitary responses towards conflict prevention ${ }^{6}$ [Elowson, Lins de Albuquerque, 2016; United Nations Development Programme, 2016].

Fifth, it asserts accountability is at the corner for any wrong doings. At times, when stateswomen and men act in ways that violate human rights, they must be liable for their actions. The international community put ICC in place to make people accountable. To this end, African states present cases of former Liberian President Charles Taylor for mass atrocities and the Islamic militant Ahmad al-Faqi al-Mahdi from Mali for cultural destruction at Timbuktu to ICC $^{7}$ [United Nations Development Programme, 2016]. This implies, African nations are benefited from freedom from fear strategy though many unpunished cases are still on the air.

Sixth, it allows AU and decision making bodies of subregional organizations and states to make informed decision based on research and thorough analysis. Security threats in the era of globalization become so dynamic. Human security concept, recognizing this fact proposes context-specific assessment and measures [Gomez, Gasper, 2013]. To this end, African nations follow professional approach to pin point the menaces and give proper response. Accordingly; CEW teams at regional and subregional levels carry out thorough assessment in identifying potential threats to human security, the African Centre for Studies and Research on Terrorism (ACSRT) conduct research on terrorism so that to create awareness and shape implementation of counter-terrorism efforts and the Institute for Security Studies (ISS) that provide evidence based policy advise and technical support for African states and communities on various security issues contribute to advance protection and empowerment [African Union Commission, 2015; Institute for Security Studies, 2013].

Seventh, it is pushing Africans to find alternative source of funding. Conflict prevention, conflict resolution and development programs demand time and money. African states due to prolonged wars and the followed economic

\footnotetext{
5 http://tdrp.net/mdrp/about_us.htm

${ }^{6}$ https://josh-benitone-rf1l.squarespace.com/s/Liberia-History.pdf 7 lbid.
} 
recession fail to cover costs of security and development programs and projects [Hussein, Gnisci, Wanjiru, 2004]. This has created dependency and donor fatigue. That is why Dambisa Mayo, a Zambian Economist stress the difficulty of making African governments accountable if it is international agencies involved in provision of basic social services like health [Al Jazeera News-Africa, 2018]. The report of Mahmood \& Ani [2017] also reveal, the budget cut of European Union (EU) on AMISOM's troop allowance by $20 \%$ (from US $\$ 1028$ to US $\$ 822$ ) per month paralyze the peacekeeping mission.

The wide range of activities to be carried out in peace, security and development areas and internal and external criticisms compel decision making body of $A U$, subregional communities and member states to work towards securing funds of peace operations. For instance, AU establishes the Peace Fund as one pillar of APSA to manage finances from members' and volunteers as well as fund-raisings [Bah, Choge-Nyangoro and other..., 2014]. Su-regional and local initiatives are also in place to strengthen ownership of financing regional peacekeeping operations. Although visible results are not attained so far, the phrase 'African solutions to African problems' has gained popularity.

\section{Conclusion}

It is to be noted that; normative, transitional and operational transitions have been made in Africa using human security concept. Visible results have been exhibited in conflict prevention and conflict resolution as well as provision of education, health and social protection. What is more, efforts are made to close the gender gap. The fact that decision making is based on professional consultation and research findings is also a positive note. Regional and local initiatives to finance peace operations of Africa might be a success in the future. In general; the security and development agenda in Africa is peoplecentered, comprehensive and promote integration. These characteristics fit to human security conception.

Having said that, the track records of human security concept is not all rosy. Sadly enough, conflicts of violent nature are still going on and likely continue throughout 2018 in states like Central African Republic (CAR) and Democratic Republic of the Congo (DRC) [ACAPS, 2017]. Tension between ethnic groups and government is still an issue in lands like Ethiopia [ACAPS, 2017]. The continent is still recognized as the poorest in the world [Wierzbicki, Tarasiuk, 2017]. To make matters worse, corruption and lack of political commitment seriously undermine security and development efforts in the continent [Hussein, Gnisci, Wanjiru, 2004]

Therefore; continental, regional and local consultations at various forms on conceptual, analytical and operational value of human security concept are needed by giving emphasis to 'what has worked so far', 'what were the gaps' and 'how can it be addressed in the future' to sustain the recorded improvements and secure a better future for Africans.

\section{REFERENCES}

ACAPS. 2018. Humanitarian Overview: An Analysis of Key Crises in to 2018. Avaialble at: https://www.acaps.org/sites/ acaps/files/products/files/acaps_humanitarian_overview_analysis_of_key_crises_into_2018.pdf (Accessed: 29.09.2018)

Acharya, A. 2007. Human Security. In: Baylis, J., Smith, S., \& Owens, P. (Eds.), The Globalization of World Politics: An Introduction to International Relations (pp.490-505). Available at: http://www.amitavacharya.com/sites/default/files/Human \%20Security.pdf (Accessed: 21.09.2018)

Adeniyi, A. 2017. The Human Cost of Uncontrolled Arms in
Africa: Cross-national Research on Seven African Countries. Available at: https://d1tn3vj7xz9fdh.cloudfront.net/s3fs-public/ file_attachments/rr-human-cost-uncontrolled-arms-africa080317-en.pdf (Accessed: 20.09.2018)

African Development Bank, Organization for Economic Cooperation and Development \& UNDP. 2017. African Economic Outlook 2017: Entrepreneurship and Industrialization. OECD Publishing, Paris. DOI: https://doi.org/10.1787/aeo-2017-en

African Union Commission. 2015. The African Peace and Security Architecture: APSA Roadmap 2016-2020. Available at: http://www. peaceau.org/uploads/2015-en-apsa-roadmapfinal.pdf (Accessed: 11.09.2018)

African Union Commission. 2018. African Union Hand Book. Available at: https://au.int/sites/default/files/pages/31829-fileafrican union handbook 2018 english-2.pdf (Accessed: 22.09.2018)

Al Jazeera News- Africa. 2018, August 2. Dambisa Moyo: Foreign aid is 'corrosive' to democracy in Africa. Best-selling author says foreign aid has undermined African governments, and praises China's role on the continent. Available at: https://www.aljazeera.$\mathrm{com} /$ news/2018/02/relying-aid-creates-dependency-syndrome180226121435444.html (Accessed: 24.09.2018)

Alkema, L., Chou,D., Hogan,D., Zhang, S., Moller, A., Gemmill, A., Fat, D. M., Boerma, T., Temmerman, M., Mathers, C., \& Say, L. 2015. Global, Regional, and National Levels and Trends in Maternal Mortality between 1990 and 2015, with Scenario-based Projections to 2030: A Systematic Analysis by the UN Maternal Mortality Estimation Inter-Agency Group. The Lancet. Vol. 387, Issue 10017: 462-474, DOI: https://doi.org/10.1016/S0140-6736(15)00838-7

Annan, K. A. 2001, December 10. Nobel Lecture. Oslo, Norway. Available at: https://www.nobelprize.org/prizes/peace/2001/ annan/lecture/ (Accessed: 15.09.2018)

Bah, A. S., Choge-Nyangoro, E., Dersso, S., Mofya, B. \& Murithi, T. 2014. The African Peace and Security Architecture: A Hand Book. Available at: http://library.fes.de/pdf-files/bueros/ aethiopien/10779.pdf (Accessed: 19.09.2018).

Collier, P. 2015. Security Threats Facing Africa and its Capacity to Respond. Journal of the Center for Complex Operations, 5 (2), 31-41. Available at: https://cco.ndu.edu/Portals/96/Documents/ prism/prism_5-2/PRISM5-2_Security_Threats.pdf (Accessed: 03.10.2018)

Commission on Human Security. 2003. Human Security Now (Final Report). Available atL https://reliefweb.int/sites/reliefweb.int/ files/resources/91BAEEDBA50C6907C1256D19006A9353-chssecurity-may03.pdf (Accessed: 01.10.2018)

Dikici, E. 2015. Guns versus Butter Tradeoff: The Theory of Defense Quality Factor. Journal of Economics, Business and Management, 3 (7), 704-709. Available at: http://www.joebm.com/ papers/270-X00007.pdf (Accessed: 01.10.2018).

Elowson, C. \& Lins de Albuquerque, A. 2016. Studies in African Security: Challenges to Peace and Security in Eastern Africa: The Role of IGAD, EAC and EASF. Available at: https://www.foi.se/ download/18.2bc30cfb157f5e989c31188/1477416021009/ FOI+Memo+5634.pdf (Accessed: 24.09.2018)

Fukuda-Parr, S. 2003. New Threats to Human Security in the Era of Globalization. Journal of Human Development, 4 (2), 167179. Available at: http://sakikofukudaparr.net/wp-content/uploads/ 2016/06/New-Threats-to-Human-Security-in-the-Era-ofGlobalization.pdf (Accessed: 28.09.2018)

Gomez, O. A. \& Gasper, D. 2013. Human Security: A Thematic Guidance Note for Regional and National Human Development Report Teams. Available at: http://hdr.undp.org/sites/default/files/ human security guidance note $r$-nhdrs.pdf (Accessed: 18.09.2018)

Guehenno, J. 2017, January 5. 10 Conflicts to watch in 2017: From Turkey to Mexico, the List of the World's most Volatile Flashpoints got a lot more unpredictable this Year. Available at: https://foreignpolicy.com/2017/01/05/10-conflicts-to-watch-in2017/ (Accessed: 30.09.2018)

Hanson, S. 2007, February 15. Disarmament, Demobilization, and Reintegration (DDR) in Africa. Available at: https:// www.cfr.org/backgrounder/disarmament-demobilization-andreintegration-ddr-africa (Accessed: 30.09.2018) 
Hussein, K., Gnisci, D., \& Wanjiru, J. 2004, December. Security and Human Security: An Overview of Concepts and Initiatives: What Implications for West Africa? (Issue Paper SAH/D 547). Available at: https://www.oecd.org/swac/publications/ 38826090.pdf (Accessed: 16.09.2018).

Institute for Security Studies. 2013. Improving Human Security in Africa. ISS Annual Review. Available at: https://oldsite.issafrica.org/uploads/2013-ISS-Annual-Review.pdf (Accessed: 19.09.2018).

Kytomaki, E. (2017). Arms Trade Treaty Signatory statesGaps and Possibilities for Treaty Universalization. Available at: https://www.saferglobe.fi/wp-ontent/uploads/2017/09/ att universalization web.pdf (Accessed: 16.09.2018).

Mahmood, O. S. \& Ani, N. C. 2017. Impact of EU funding dynamics on AMISOM. Institute for Security Studies (ISS,) 16th East African Report. Available at: https://issafrica.s3.amazonaws.com/site/uploads/ear16.pdf (Accessed: 13.09.2018)

Obama, B. H. 2009, December 10. Nobel Lecture: A Just and Lasting Peace. Oslo, Nonway. Available at: https://www.nobelprize.org/prizes/peace/2009/obama/26183-nobel-lecture-2009/ (Accessed: 11.09.2018)

Owen, T. 2004. Challenges and Opportunities for Defining and Measuring Human Security. Disarmament Forum Human Rights, Human Security and Disarmament, United Nations Institute for Disarmament Research, (3): 15-23. Available at: http:// www.taylorowen.com/Articles/2004_Disarmament_Forum.pdf (Accessed: 11.09.2018)

Owen, T. 2008. Measuring Human Security: Methodological Challenges and the Importance of Geographically Referenced Determinants. In: Liotta, P. H., Mouat, D. A., Kepner, W. G., \& Lancaster, J. M. (Eds.), Environmental Change and Human Security: Recognizing and Acting on Hazard Impacts: 35-64. Available at: http://www.taylorowen.com/Articles/2008\%20Owen\%20-\%20Measuring\%20HS\%20Chapter.pdf (Accessed: 16.09.2018).

Paris, R. 2001. Human Security: Paradigm Shift or Hot Air?
International Security, 26 (2), 87-102. Available at: http:// aix1.uottawa.ca/ rparis/Paris.2001.IS.Human\%20Security.pdf (Accessed: 14.09.2018)

United Nations Development Programme. 1994. Human Development Report 1994. Available at: http://hdr.undp.org/sites/ default/files/reports/255/hdr_1994_en_complete_nostats.pdf (Accessed: 14.09.2018).

United Nations Development Programme. 2005. Human Development Report 2005: Internal Cooperation at a CrossroadsAid, Trade and Security in an Unequal World. Available at: http:// hdr.undp.org/sites/default/files/reports/266/hdr05_complete.pdf (Accessed: 22.09.2018)

United Nations Development Programme. 2016. Human Development Report 2016: Human Development for Everyone. Available at: http://hdr.undp.org/sites/default/files/2016_human_development report.pdf (Accessed: 22.09.2018)

United Nations Educational, Scientific and Cultural Organization. 2008. Human Security: Approaches and Challenges. Available at: http://unesdoc.unesco.org/images/0015/001593/ 159307e.pdf (Accessed: 24.09.2018)

United Nations Trust Fund for Human Security. (2017, Feb. 16-17). Fifteenth Coordination Meeting on International Migration. Available at: https://www.un.org/humansecurity/wp-content/ uploads/2017/10/UNTFHS-and-Implementation-of-the-New-YorkDeclaration-for-Refugees-and-Migrants-1.pdf

Wierzbicki, S. \& Tarasiuk, R. 2017. The Role of African International Organizations as a Classic Example of Ensuring Safety in the Region. World Scientific News, 78, 328-334. Available at: http://www.worldscientificnews.com/wp-content/uploads/2017/ 05/WSN-78-2017-328-334.pdf (Accessed: 21.09.2018)

World Health Regional Organization Office for Africa. 2017. 2016 Annual Report: Communicable Diseases Cluster. Available at: https://reliefweb.int/sites/reliefweb.int/files/resources/WHO\%20AFRO\%20CDS\%20Annual\%20Report\%202016\%20web\%20version_1_0.pdf (Accessed: 21.09.2018)

\section{Волдетсадік Мессаш Кассає,} аспірантка з питань миру та безпеки,

Інститут досліджень миру та безпеки (IPSS), Університет Аддіс-Абеби, Ефіопія

\section{КОРИСНІСТЬ КОНЦЕПЦІї ЛЮДСЬКОЇ БЕЗПЕКИ: АФРИКАНСЬКА ПЕРСПЕКТИВА}

Стаття присвячена аналізу цінності концепції людської безпеки для африканських народів. Цінність концепції розглядається в сімох різних аспектах. Зокрема, як концепція: 1) використовується для інформування національних політиків, що їхня відповідальність виходить за рамки державного суверенітету; 2) декларує спільну відповідальність за місцевий і регіональний мир та безпеку; 3) сприяє поліпшенню соціально-економічних аспектів; 4) тлумачить сутність актуального конфлікту; 5) формує почуття відповідальності за будь-які неправильні вчинки; 6) сприяє прийняттю обґрунтованих рішень інституціями субрегіональних організацій та штатів; 7) стимулює африканців до пошуків альтернативного джерела фрінансування.

Зазначено, що використання концепції людської безпеки забезпечує адекватні соціальні трансформації в сучасній Африці, які проявляються у: запобіганні соціальних конфліктів різної природи; забезпеченні реалізації прав людини на освіту, охорону здоров'я та соціальний захист; подоланні гендерного розриву.

Зауважено, що положення концепції можуть використовуватися для подолання поточних конфліктів в Африці, зокрема в Центральній Африканській Республіці та Демократичній Республіці Конго; для підвищення рівня економічної спроможності континенту; розвитку його системи безпеки.

Наголошено на необхідності подальших консультацій щодо аналітичної та експлуатаційної цінності концепції безпеки в частинах аналізу наявних безпекових ресурсів, виявлення необхідних способів їх покращення для забезпечення кращого майбутнього для африканців.

Ключові слова: Африка; людський розвиток; безпека людини; безпека держави; безпека.

\section{ЛПТРАТУРA}

ACAPS. Humanitarian Overview: An Analysis of Key Crises in to 2018. 2018. URL: https://www.acaps.org/sites/acaps/files/ products/files/acaps_humanitarian_overview_analysis_of_key_crises_into_2018.pdf (Accessed: 29.09.2018).

Acharya A. Human Security. In: The Globalization of World Politics: An Introduction to International Relations / Baylis J., Smith S. \& Owens P. (Eds.). 2007. pp. 490-505. URL: http://www.amitavacharya.com/sites/default/files/Human\%20Security.pdf (Accessed: 21.09.2018).

Adeniyi A. The Human Cost of Uncontrolled Arms in Africa: Cross-national Research on Seven African Countries. 2017. URL: https:/ /d1tn3vj7xz9fdh.cloudfront.net/s3fs-public/file attachments/rr-human-cost-uncontrolled-arms-africa-080317-en.pdf.

African Development Bank, Organization for Economic Co-operation and Development \& UNDP. African Economic Outlook 2017: Entrepreneurship and Industrialization. OECD Publishing, Paris. DOI: https://doi.org/10.1787/aeo-2017-en. 
African Union Commission. The African Peace and Security Architecture: APSA Roadmap 2016-2020. 2015. URL: http:// www.peaceau.org/uploads/2015-en-apsa-roadmap-final.pdf (Accessed: 11.09.2018).

African Union Commission. African Union Hand Book. 2018. URL: https://au.int/sites/default/files/pages/31829-fileafrican_union_handbook_2018_english-2.pdf (Accessed: 22.09.2018).

Al Jazeera News-Africa. Dambisa Moyo: Foreign aid is 'corrosive' to democracy in Africa. Best-selling author says foreign aid has undermined African governments, and praises China's role on the continent. 2018, August 2. URL: https://www.aljazeera.com/news/ 2018/02/relying-aid-creates-dependency-syndrome-180226121435444.html (Accessed: 24.09.2018).

Alkema L., Chou D., Hogan D., Zhang S., Moller A., Gemmill A., Fat D. M., Boerma T., Temmerman M., Mathers C. \& Say L. Global, Regional, and National Levels and Trends in Maternal Mortality between 1990 and 2015, with Scenario-based Projections to 2030: A Systematic Analysis by the UN Maternal Mortality Estimation Inter-Agency Group. The Lancet. 2015. Vol. 387, Issue 10017: 462-474. DOI: https://doi.org/10.1016/S0140-6736(15)00838-7.

Annan K. A. Nobel Lecture. Oslo, Norway. 2001, December 10. URL: https://www.nobelprize.org/prizes/peace/2001/annan/lecture/ (Accessed: 15.09.2018)

Bah A. S., Choge-Nyangoro E., Dersso S., Mofya B. \& Murithi T. The African Peace and Security Architecture: A Hand Book. 2014. URL: http://library.fes.de/pdf-files/bueros/aethiopien/10779.pdf (Accessed: 19.09.2018).

Collier P. Security Threats Facing Africa and its Capacity to Respond. Journal of the Center for Complex Operations. 2015. 5 (2), 31-41. URL: https://cco.ndu.edu/Portals/96/Documents/prism/prism_5-2/PRISM5-2_Security_Threats.pdf (Accessed: 03.10.2018).

Commission on Human Security. Human Security Now (Final Report). 2003. URL: https://reliefweb.int/sites/reliefweb.int/files/ resources/91BAEEDBA50C6907C1256D19006A9353-chs-security-may03.pdf (Accessed: 01.10.2018).

Dikici E. Guns versus Butter Tradeoff: The Theory of Defense Quality Factor. Journal of Economics, Business and Management. 2015. 3 (7), 704-709. URL: http://www.joebm.com/papers/270-X00007.pdf (Accessed: 01.10.2018).

Elowson C. \& Lins de Albuquerque A. Studies in African Security: Challenges to Peace and Security in Eastern Africa: The Role of IGAD, EAC and EASF. 2016. URL: https://www.foi.se/download/18.2bc30cfb157f5e989c31188/1477416021009/FOI+Memo+5634.pdf (Accessed: 24.09.2018).

Fukuda-Parr S. New Threats to Human Security in the Era of Globalization. Journal of Human Development. 2003. 4 (2), $167-179$. URL: http://sakikofukudaparr.net/wp-content/uploads/2016/06/New-Threats-to-Human-Security-in-the-Era-of-Globalization.pdf (Accessed: 28.09.2018).

Gomez O. A. \& Gasper D. Human Security: A Thematic Guidance Note for Regional and National Human Development Report Teams. 2013. URL: http://hdr.undp.org/sites/default/files/human_security_guidance_note_r-nhdrs.pdf (Accessed: 18.09.2018).

Guehenno J. 10 Conflicts to watch in 2017: From Turkey to Mexico, the List of the World's most Volatile Flashpoints got a lot more unpredictable this Year. 2017. URL: https://foreignpolicy.com/2017/01/05/10-conflicts-to-watch-in-2017/ (Accessed: 30.09.2018).

Hanson S. Disarmament, Demobilization, and Reintegration (DDR) in Africa. 2007, February 15. URL: https://www.cfr.org/backgrounder/ disarmament-demobilization-and-reintegration-ddr-africa (Accessed: 30.09.2018).

Hussein K., Gnisci D. \& Wanjiru J. Security and Human Security: An Overview of Concepts and Initiatives: What Implications for West Africa? (Issue Paper SAH/D 547). 2004, December. URL: https://www.oecd.org/swac/publications/38826090.pdf (Accessed: 16.09.2018).

Institute for Security Studies. Improving Human Security in Africa. ISS Annual Review. 2013. URL: https://oldsite.issafrica.org/ uploads/2013-ISS-Annual-Review.pdf (Accessed: 19.09.2018).

Kytomaki E. Arms Trade Treaty Signatory states- Gaps and Possibilities for Treaty Universalization. 2017. URL: https:// www.saferglobe.fi/wp-ontent/uploads/2017/09/att universalization web.pdf (Accessed: 16.09.2018).

Mahmood O. S. \& Ani N. C. Impact of EU funding dynamics on AMISOM. Institute for Security Studies (ISS,) 16th East African Report. 2017. URL: https://issafrica.s3.amazonaws.com/site/uploads/ear16.pdf (Accessed: 13.09.2018).

Obama B. H. Nobel Lecture: A Just and Lasting Peace. Oslo, Norway. 2009, December 10. URL: https://www.nobelprize.org/prizes/ peace/2009/obama/26183-nobel-lecture-2009/ (Accessed: 11.09.2018).

Owen T. Challenges and Opportunities for Defining and Measuring Human Security. Disarmament Forum Human Rights, Human Security and Disarmament, United Nations Institute for Disarmament Research. 2004. (3): 15-23. URL: http://www.taylorowen.com/ Articles/2004 Disarmament Forum.pdf (Accessed: 11.09.2018).

Owen T. Measuring Human Security: Methodological Challenges and the Importance of Geographically Referenced Determinants. In: Environmental Change and Human Security: Recognizing and Acting on Hazard Impacts / Liotta P. H., Mouat D. A., Kepner W. G., \& Lancaster J. M. (Eds.). 2008. 35-64. URL: http://www.taylorowen.com/Articles/2008\%200wen $\% 20-\% 20 \mathrm{Measuring} \% 20 \mathrm{HS} \%$ 20Chapter.pdf (Accessed: 16.09.2018).

Paris R. Human Security: Paradigm Shift or Hot Air? International Security. 2001. 26 (2), 87-102. URL: http://aix1.uottawa.ca/ rparis/ Paris.2001.IS.Human\%20Security.pdf (Accessed: 14.09.2018).

United Nations Development Programme. Human Development Report 1994. URL: http://hdr.undp.org/sites/default/files/reports/ 255/hdr 1994_en_complete_nostats.pdf (Accessed: 14.09.2018).

United Nations Development Programme. Human Development Report 2005: Internal Cooperation at a Crossroads-Aid, Trade and Security in an Unequal World. 2005. URL: http://hdr.undp.org/sites/default/files/reports/266/hdr05 complete.pdf (Accessed: 22.09.2018). United Nations Development Programme. Human Development Report 2016: Human Development for Everyone. 2016. URL: http:/ /hdr.undp.org/sites/default/files/2016 human development report.pdf (Accessed: 22.09.2018).

United Nations Educational, Scientific and Cultural Organization. Human Security: Approaches and Challenges. 2008. URL: http:// unesdoc.unesco.org/images/0015/001593/159307e.pdf (Accessed: 24.09.2018).

United Nations Trust Fund for Human Security. Fifteenth Coordination Meeting on International Migration. 2017, Feb. 16-17. URL: https://www.un.org/humansecurity/wp-content/uploads/2017/10/UNTFHS-and-Implementation-of-the-New-York-Declaration-forRefugees-and-Migrants-1.pdf (Accessed: 19.09.2018).

Wierzbicki S. \& Tarasiuk R. The Role of African International Organizations as a Classic Example of Ensuring Safety in the Region. World Scientific News. 2017. 78, 328-334. URL: http://www.worldscientificnews.com/wp-content/uploads/2017/05/WSN-78-2017328-334.pdf (Accessed: 21.09.2018).

World Health Regional Organization Office for Africa. 2016 Annual Report: Communicable Diseases Cluster. 2017. URL: https:// reliefweb.int/sites/reliefweb.int/files/resources/WHO\%20AFRO\%20CDS\%20Annual\%20Report\%202016\%20web\%20version 1 0.pdf (Accessed: 21.09.2018).

(c) Woldetsadik Messash Kassaye

Надійшла до редакції 10.10.2018

СХІД № 5 (157) вересень-эновтень 2018 р. 